\title{
Gene networking in colistin-induced nephrotoxicity reveals an adverse outcome pathway triggered by proteotoxic stress
}

\author{
EUN HEE LEE ${ }^{1 *}$, SOOJIN KIM $^{1 *}$, MI-SUN CHOI ${ }^{1 *}$, HEEYOUNG YANG $^{1}$, \\ SE-MYO PARK ${ }^{1}$, HYUN-A OH ${ }^{1}$, KYOUNG-SIK MOON ${ }^{1}$, JI-SEOK HAN ${ }^{1}$, \\ YONG-BUM KIM $^{1}$, SEOKJOO YOON ${ }^{1,2}$ and JUNG-HWA OH ${ }^{1}$ \\ ${ }^{1}$ Department of Predictive Toxicology, Korea Institute of Toxicology, Daejeon 34114; ${ }^{2}$ Department of Human and \\ Environmental Toxicology, University of Science and Technology, Daejeon 34113, Republic of Korea
}

Received August 9, 2018; Accepted December 17, 2018

DOI: 10.3892/ijmm.2019.4052

\begin{abstract}
Colistin has been widely used for the treatment of infections of multidrug-resistant Gram-negative bacteria, despite the fact that it induces serious kidney injury as a side effect. To investigate the mechanism underlying its nephrotoxicity, colistin methanesulfonate sodium (CMS; 25 or $50 \mathrm{mg} / \mathrm{kg}$ ) was administered via intraperitoneal injection to Sprague-Dawley rats daily over 7 days. Serum biochemistry and histopathology indicated that nephrotoxicity occurred in the rats administered with CMS. Whole-genome microarrays indicated 894 differentially expressed genes in the group treated with CMS (analysis of variance, false discovery rate $<0.05$, fold-change $\geq 1.3$ ). Gene pathway and networking analyses revealed that genes associated with proteotoxic stress, including ribosome synthesis, protein translation, and protein folding, were significantly associated with the nephrotoxicity induced by CMS. It was found that colistin inhibited the expression of the target genes heat shock factor 1 and nuclear factor erythroid-2-related factor-2, which are associated with proteostasis, and that nephrotoxicity of CMS may be initiated by proteotoxic stress due to heat shock response inhibition, leading to oxidative stress, endoplasmic reticulum stress, cell cycle arrest and apoptosis, eventually leading to cell death. A putative adverse outcome pathway was constructed based on the integrated gene networking data, which may clarify the mode of action of colistin-induced nephrotoxicity.
\end{abstract}

Correspondence to: Dr Jung-Hwa Oh or Dr Seokjoo Yoon, Department of Predictive Toxicology, Korea Institute of Toxicology, 141 Gajeong-ro, Yuseong-gu, Daejeon 34114, Republic of Korea

E-mail: jhoh@kitox.re.kr

E-mail: sjyoon@kitox.re.kr

*Contributed equally

Key words: colistin, nephrotoxicity, proteotoxic stress, oxidative stress, adverse outcome pathways

\section{Introduction}

It is well known that increases in the multidrug resistance of Gram-negative bacteria, in particular, Pseudomonas aeruginosa, Acinetobacter baumannii and Klebsiella pneumonia, are a clinical problem. Colistin is a drug used clinically for infection caused by multidrug-resistant Gram-negative bacteria $(1,2)$. Its use was abandoned in the early 1970s due to severe adverse effects on the kidney, however, the drug has been reintroduced to treat multidrug-resistant infections $(3,4)$. Colistin is now commercially available as colistin sulfate and colistin methanesulfonate sodium (CMS). CMS is the prodrug form of colistin most commonly used in clinical applications, and is less toxic than colistin sulfate $(5,6)$. Most of the administered CMS is excreted by renal clearance, and the rest is converted into the active form of colistin within the urinary tract and reabsorbed by the renal tubule $(1,7)$.

Colistin has been used recently due to the increase in nosocomial infections; although the frequency of nephrotoxicity has reduced, adverse effects continue to be reported in clinical studies $(8,9)$. The nephrotoxicity induced by colistin treatment is dose-dependent and reversible, and acute tubular necrosis can occur in the kidneys of patients $(6,9,10)$. Histopathological studies involving animals have shown that colistin is involved in focal irregular dilation of the renal tubules and the degeneration and regeneration of epithelial cells (6). It has also been reported that colistin treatment results in proteinuria and hematuria, and increases the concentrations of urea and creatinine in the blood (11). Acute tubular necrosis occurs as a result of a colistin-dependent increase in cell membrane permeability of the tubular epithelium (12).

Although the nephrotoxicity of colistin has been reported, the molecular mechanism underlying its nephrotoxicity remains to be fully elucidated. Several toxic mechanisms underlying the nephrotoxicity induced by colistin treatment have been suggested. Ozkan et al (13), reported that caspase-mediated apoptosis occurred following colistin treatment, and several genes, including caspase 1, calpain 1, inducible nitric oxide synthase and endothelial nitric oxide synthase, were identified as key regulators. Dai et al (14), reported that apoptosis was induced following colistin treatment via the mitochondrial, death receptor and endo- 
plasmic reticulum pathways. An enriched gene signature of cell cycle arrest was also found according to the relevance of the nephrotoxicity of colistin (15). Among the suggested mechanisms, oxidative stress is considered to be key factor associated with colistin-induced nephrotoxicity. In support of this, nephrotoxicity is prevented by treatment with several antioxidants, including melatonin, ascorbic acid, astaxanthin and vitamin E $(12,16,17)$. Lycopene reportedly activates the nuclear factor erythroid-2-related factor-2 (Nrf2)/heme oxygenase-1 pathway and has a protective effect on colistin-induced nephrotoxicity (18).

Although several mechanisms have been suggested, previous investigations have been limited to the evaluation of initiating events of colistin-induced nephrotoxicity. Whole genome and gene networking analysis may provide additional information regarding the mechanisms of toxicity, and analysis of the master regulators and transcription factors of regulated genes may provide key clues to the regulation of this toxicity (19). To understand the events during initial nephrotoxicity induced by colistin, the present study analyzed a comprehensive gene expression profile in rat kidneys exhibiting nephrotoxicity induced by colistin treatment. Adverse outcome pathways (AOPs) are conceptual frameworks of the biological events leading to adverse effects, and provide a systematic approach for organizing mechanisms of toxicity $(20,21)$. Genomic datasets can provide clues to determining potential molecular initiating events (MIEs) and key events (KEs) at the molecular level, and can be used to develop the AOP framework (22). Based on integrated analysis of gene networking in the rat kidney following colistin treatment, the toxicity pathway was evaluated and a putative AOP framework was developed for colistin-induced renal toxicity. This AOP framework provides a better understanding of the mode of action of renal toxicity induced by antibiotics including colistin.

\section{Materials and methods}

Animals and drug treatment. All animal experiments were performed under the guidance of the Institutional Animal Care and Use Committee (IACUC) of the Korea Institute of Toxicology (Daejeon, China). Sprague-Dawley rats (24 males, 8 weeks old, 240-260 g) were purchased from Orient Bio, Inc. (Seongnam, Korea) and acclimated for 1 week prior to the experiment. All rats were housed under standard laboratory conditions on a 12-h light/dark cycle, under controlled temperature $\left(23 \pm 3^{\circ} \mathrm{C}\right)$ and humidity $(50 \pm 20 \%)$. The rats were divided into groups of eight and were fed standard food pellets and water ad libitum. The CMS was purchased from Samchundang Pharm (Seoul, Korea), diluted with $0.9 \%$ saline (Dai Han Pharm, Co., Ansan, Korea), and administered at concentrations of 0,25 , and $50 \mathrm{mg} / \mathrm{kg}$ body weight. Each rat was injected with $0.9 \%$ saline (a vehicle control) or CMS via intraperitoneal injection daily for 7 days. Prior to sacrifice, all rats were fasted overnight and anesthetized by isoflurane inhalation. All experiments were approved by the IACUC of the Korea Institute of Toxicology (approval no. 1404-0120) and conducted in accordance with the Association of Assessment and Accreditation of Laboratory Animal Care International guidelines.
Organ weights, serum biochemistry and histopathology. The total body weight and weights of the right and left kidneys were measured, and the relative organ weight ratio was calculated. Blood samples of $\sim 1.5 \mathrm{ml}$ were drawn from the inferior vena cava and serum samples were separated by centrifugation at 2,000 $\mathrm{xg}$ for $10 \mathrm{~min}$ at room temperature. The serum chemistry parameters were measured using a Toshiba 120 FR chemistry analyzer (Toshiba Corporation, Tokyo, Japan). For histopathological evaluation, the tissues were fixed in paraformaldehyde (4\%) and embedded in paraffin. The paraffin blocks were sectioned at $4 \mu \mathrm{m}$ thickness using a microtome. The sectioned tissues were stained with hematoxylin and eosin. All histopathological results were reviewed by pathology experts at Korea Institute of Toxicology in a blinded-manner.

RNA extraction. Following animal sacrifice, the whole right kidneys were extracted and frozen immediately in liquid nitrogen. The frozen samples were homogenized with a TissueLyser (Qiagen GmbH, Hilden, Germany) and total RNA was purified using an RNeasy ${ }^{\circledR}$ Mini kit (Qiagen $\mathrm{GmbH}$ ) according to the manufacturer's protocol. The concentration and quality of total RNA were determined using a NanoDrop ${ }^{\mathrm{TM}}$ spectrophotometer (NanoDrop Technologies; Thermo Fisher Scientific, Inc., Waltham, MA, USA) and the RNA integrity was measured using a 2100 Bioanalyzer (Agilent Technologies, Inc., Santa Clara, CA, USA).

Microarray experiments. The Affymetrix GeneChip Rat 230 2.0 (Affymetrix; Thermo Fisher Scientific, Inc.) was used for microarray analysis. Three rats were randomly selected from each CMS-treated group $(0,25$, and $50 \mathrm{mg} / \mathrm{kg})$. Microarray analysis was conducted according to the GeneChip ${ }^{\circledR} 3^{\prime}$ expression array user guide (Affymetrix; Thermo Fisher Scientific, Inc.). cDNA synthesis, cRNA synthesis, biotin labeling, cRNA purification and fragmentation were performed according to the manufacturer's protocols (Affymetrix; Thermo Fisher Scientific, Inc.). The microarrays were hybridized at $45^{\circ} \mathrm{C}$ at $60 \mathrm{rpm}$ for $16 \mathrm{~h}$. The microarrays were stained and washed using a Fluidics Station 450 system (Affymetrix; Thermo Fisher Scientific, Inc.). A GeneChip ${ }^{\circledR}$ Scanner 3000 (Affymetrix; Thermo Fisher Scientific, Inc.) was used to scan the microarrays. The reproducibility of the microarray experiments was confirmed using well-defined quality control criteria according to the manufacturer's protocol. The microarray data was deposited into the Gene Expression Omnibus database (https://www.ncbi.nlm.nih.gov/geo/; no. GSE121792).

Bioinformatics analysis of differentially expressed genes (DEGs). To perform the preprocessing and statistical analysis of the microarray data, GeneSpring GX v.13.0 analysis software was used (Agilent Technologies, Inc.). Normalization was performed using robust multichip average quantile median normalization. To determine significance, one-way analysis of variance was used $(\mathrm{P} \leq 0.05)$ followed by Tukey's honest significant difference (HSD) post hoc test, and the Benjamini-Hochberg false discovery rate (FDR; $\mathrm{P} \leq 0.05$ ) multiple testing correction was performed. The DEGs were selected based on a 1.3-fold-change compared with the control samples, as described previously (23). Venn diagram analysis was used to determine the expressed genes that were common 
among groups. Functional enrichment of the DEGs was analyzed using Ingenuity Pathway Analysis (IPA) software v.9.0 (Ingenuity Systems, Redwood City, CA, USA) (24). The enriched canonical pathways were generated through the Ingenuity Systems Knowledge Base and calculated using a right-tailed Fisher's exact test. Upstream regulators were selected via IPA causal analysis. Cytoscape software iRegulon v.3.2 (www.cytoscape.org) (25) was used to select the transcription factors, as described previously (26).

The protein-protein interactions (PPIs) of the common expressed genes were analyzed using STRING software v.10 (http://string-db.org) (27). The medium confidence score (0.400) was used to select the network of PPIs of the DEGs $(25 \mathrm{mg} / \mathrm{kg})$. This score is the approximate probability that a predicted link exists between two proteins in the same Kyoto Encyclopedia of Genes and Genomes (KEGG) pathway (www. genome.jp/kegg/) (28). The PPI network was also selected using a high confidence score $(0.700)$ in the DEGs $(50 \mathrm{mg} / \mathrm{kg}$-treated group) due to the high number of DEGs.

Validation via reverse transcription-quantitative polymerase chain reaction ( $R T-q P C R$ ) analysis. The DEGs were validated by RT-qPCR analysis. The primers were purchased from Bioneer Corporation (Daejeon, Korea). Total RNA $(2 \mu \mathrm{g})$ was reverse transcribed with SuperScript ${ }^{\mathrm{TM}}$ II (Invitrogen; Thermo Fisher Scientific, Inc.) using an oligo-dT primer according to the manufacturer's protocol. The cDNA samples were stored at $-20^{\circ} \mathrm{C}$ until use. The RT-qPCR procedure was performed using a $20-\mu \mathrm{l}$ reaction volume containing $2 \mu \mathrm{l}(5 \mathrm{pM})$ forwardand reverse-specific primers, $10 \mu \mathrm{L}$ of SYBR ${ }^{\circledR}$-Green Master mix (Applied Biosystems; Thermo Fisher Scientific, Inc.), $2 \mu \mathrm{l}$ of cDNA and $6 \mu \mathrm{l}$ of nuclease-free water. The cDNA was amplified using a StepOne ${ }^{\mathrm{TM}}$ and StepOnePlus ${ }^{\mathrm{TM}}$ Real-Time PCR system (Applied Biosystems; Thermo Fisher Scientific, Inc.) according to the manufacturer's protocol. The following amplification protocol was used: Denaturation program $\left(10 \mathrm{~min}\right.$ at $95^{\circ} \mathrm{C}$ for $10 \mathrm{~min}, 60^{\circ} \mathrm{C}$ for $10 \mathrm{sec}, 72^{\circ} \mathrm{C}$ for $60 \mathrm{sec}$ ), melting curve program $\left(60-95^{\circ} \mathrm{C}\right.$ with a heating rate of 0.1 per second and a continuous fluorescence measurement) and a final cooling step to $40^{\circ} \mathrm{C}$. The sequences of the primers used were as follow: DnaJ heat shock protein family (Hsp40) member B1 (Dnajb1; Hsp40), forward 5'-GTC CCT GTC AAC TAC TGC CT-3' and reverse 5'-TGA GTC GAA TGG TCA GAG CA'; heat shock protein $(H s p) h l$, forward 5'-CCA AGA TCG CAG CAG ACT TC-3' and reverse 5'-TCA TCC ACT CCA TCA CCT CG-3'; Hsp90aal, forward 5'-GCC AGT TTG GTG TTG GTT TT-3' and reverse 5'-ACC CAT TGG TTC ACC TGT GT-3'; glutathione peroxidase 2 (Gpx2) forward 5'-ATA TTG TCC CCT TGC CTT CC-3' and reverse 5'-CAG ACT TAG AGC CCC CAG TG-3'; glutathione-disulfide reductase (Gsr), forward 5'-CAA CAT CCC TAC CGT GGT CT-3' and reverse 5'-TGA AGG CGG TCG AGT AGA TT-3'; glutathione S-transferase (Gst)a3, forward 5'-GGA GGC CAA CAC GTT TTC TA-3' and reverse 5'-CCA AAT AGC ATC CCA GCA AT-3'; Gstm2, forward 5'-CAC AAG ATC ACC CAG AGC AA-3' and reverse 5'-AAA CGT CCA CAC GAA TCC TC-3'; Gstt2, forward 5'-TTT TCT GGC TCC TTT TCT GG-3' and reverse 5'-GGG TCT CCT ATT GGT TGT GC-3'; superoxide dismutase 1 (Sod1), forward 5'-ATT GGC CGT ACT ATG GTG GT-3' and reverse 5'-CCA ATC ACA CCA CAA GCC
AA-3'; $\beta$-actin, forward 5'-GTC GTA CCA CTG GCA TTG TG-3' and reverse 5'-CTC TCA GCT GTG GTG GTG AA-3'. The $\beta$-actin primers were used as an internal control and fold changes in expression were calculated according to the $2-{ }^{\Delta \Delta} \mathrm{Cq}$ method (29).

AOP construction. The structure of an AOP is composed of MIEs, measurable KEs, KE relationships (KERs) and adverse outcomes (AOs). The MIE initiates toxicity through the interaction between a chemical initiator and a molecular target within cells. The KEs are initiated by the MIE and connected by KERs, which are sequentially effected from cells to tissues. Therefore, the KEs are individual cellular toxicity response pathways that connect the MIE with the AO. The KEs and the KERs were selected using pathway analysis. An AOP is basically composed of an MIE, KEs, an AO and KERs, and this framework is a modular system in which multiple AOPs share a network. The -omics data together with biochemical and histopathological results were used to build the AOP framework. Relevant data from the literature were also used to support and connect this model.

Statistical analysis. Organ weights, and the concentrations and activity levels of substrates and proteins in the serum were analyzed using one-way analysis of variance following by Dunnet's post hoc test for multiple comparison analysis. Statistical analyses were performed with SAS 9.4 (SAS institute, Cary, NC, USA; 8 replicates per group). $\mathrm{P}<0.05$ indicated a statistically significant difference.

\section{Results and Discussion}

Serum biochemical analysis and histopathology. In clinical studies, it is recommended that CMS is administrated to patients at $\sim 6.67-13.3 \mathrm{mg} / \mathrm{kg} /$ day $(2.5-5 \mathrm{mg} / \mathrm{kg} /$ day colistin base activity) in 2-4 intravenous doses (5). Based on pharmacokinetics, CMS at $9 \mathrm{mg} / \mathrm{kg} / 24 \mathrm{~h}$ in humans is equivalent to $30 \mathrm{mg} / \mathrm{kg} / 12 \mathrm{~h}$ in the rat via jugular vein (6). A previous clinical study reported that intravenous injection of 2.5-5 mg/ $\mathrm{kg} /$ day CMS for 14 days induced renal injury in a patient (8). An animal study showed that intraperitoneal injection of $16 \mathrm{mg} / \mathrm{kg} /$ day CMS for 15 days induced nephrotoxicity in a murine model, and that there was no significant difference in toxicity between intraperitoneal and intravenous injection (15). Therefore, the dosage and duration of CMS for the Sprague-Dawley rats were determined from preliminary studies that showed nephrotoxicity. In the present study, the dosages for inducing initial and moderate damage were selected for analysis of the initial molecular events causing nephrotoxicity. The respective doses of CMS were set to 25 and $50 \mathrm{mg} / \mathrm{kg}$ via intraperitoneal injection, and each rat was injected with a vehicle control or CMS via intraperitoneal injection daily for 7 days. The total body weights were decreased and the relative kidney ratio was increased in the $50 \mathrm{mg} / \mathrm{kg}$ CMS-treated group, with no significant change detected in the $25 \mathrm{mg} / \mathrm{kg}$ CMS-treated group (Table I). As shown in Fig. 1, serum biochemical analysis indicated that total cholesterol, blood urea nitrogen (BUN), serum creatinine (CREA), and blood calcium were significantly increased in the $50 \mathrm{mg} / \mathrm{kg}$ CMS-treated rats. BUN and CREA are representative serum markers of nephrotoxicity, and it is known that calcium 
Table I. Absolute and relative organ weights in rats following 7 days of CMS administration.

\begin{tabular}{lccccc}
\hline & & \multicolumn{2}{c}{ Liver } & \multicolumn{2}{c}{ Kidney } \\
\cline { 3 - 6 } $\begin{array}{l}\mathrm{CMS} \\
(\mathrm{mg} / \mathrm{kg})\end{array}$ & $\begin{array}{c}\text { Terminal } \\
\text { body weight }(\mathrm{g})\end{array}$ & $\begin{array}{l}\text { Absolute } \\
\text { weight }(\mathrm{g})\end{array}$ & $\begin{array}{c}\text { Relative } \\
\text { weight }(\%)\end{array}$ & $\begin{array}{c}\text { Absolute } \\
\text { weight }(\mathrm{g})\end{array}$ & $\begin{array}{c}\text { Relative } \\
\text { weight }(\%)\end{array}$ \\
\hline 0 & $337.8 \pm 12.4$ & $10.09 \pm 0.67$ & $2.99 \pm 0.13$ & $2.68 \pm 0.20$ & $0.79 \pm 0.06$ \\
25 & $323.4 \pm 18.6$ & $9.43 \pm 0.61^{\mathrm{a}}$ & $2.95 \pm 0.12$ & $2.58 \pm 0.24$ & $0.81 \pm 0.05$ \\
50 & $280.7 \pm 30.7^{\mathrm{b}}$ & $8.29 \pm 0.62^{\mathrm{b}}$ & $3.05 \pm 0.13$ & $3.93 \pm 1.15^{\mathrm{a}}$ & $1.47 \pm 0.53^{\mathrm{b}}$ \\
\hline
\end{tabular}

Values are expressed as the mean \pm standard deviation for each group of rats. Data were analysed using one-way analysis of variance followed by a Dunnet's post hoc test. ${ }^{\mathrm{a}} \mathrm{P}<0.05$ and ${ }^{\mathrm{b}} \mathrm{P}<0.01$ vs. controls. CMS, colistin methanesulfonate.
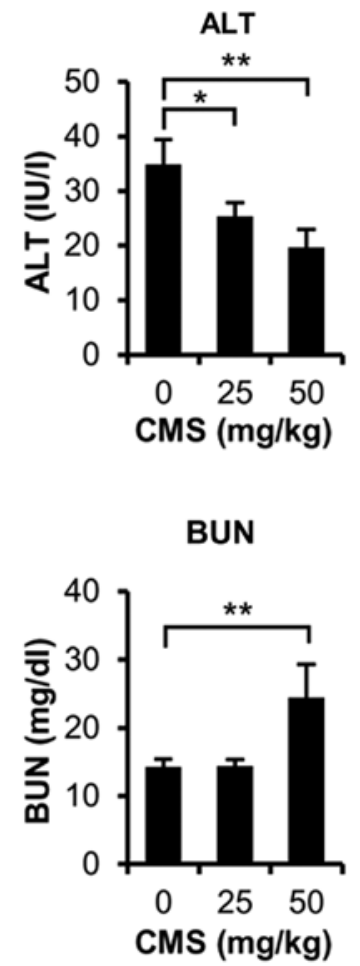

AST

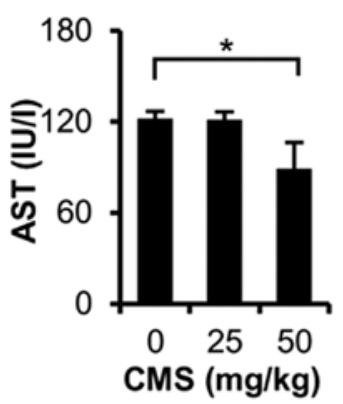

CREA

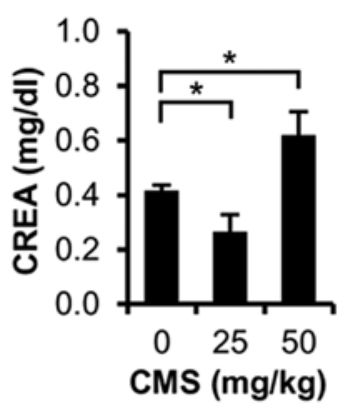

TCHO
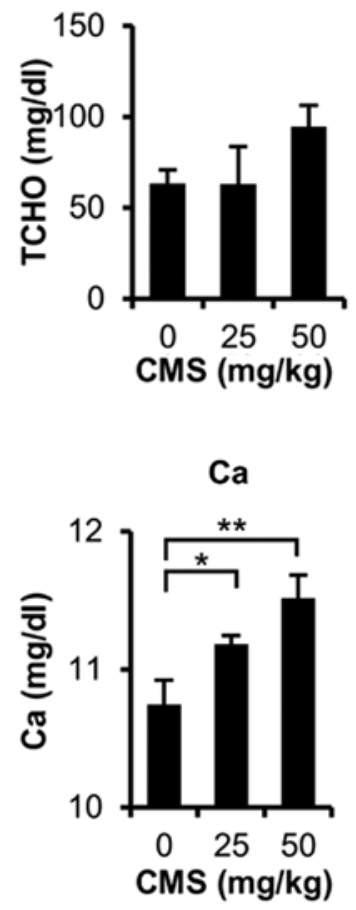

Figure 1. Serum biochemical values in CMS-treated rats. Values are represented as the mean \pm standard deviation from each group. Data were analysed using one-way analysis of variance following by Dunnet's post hoc test. " $\mathrm{P}<0.05$ and ${ }^{* *} \mathrm{P}<0.01$. CMS, colistin methanesulfonate; ALT, alanine aminotransferase; AST, aspartate aminotransferase; TCHO, total cholesterol; BUN, blood urea nitrogen; CREA, creatinine; $\mathrm{Ca}$, calcium.

increases following kidney dysfunction. Histopathological analysis revealed that there were no significant lesions in the liver, but renal toxicity was observed in the CMS-treated rats (Table II). In the $25 \mathrm{mg} / \mathrm{kg} \mathrm{CMS}$-treated group, tubular basophilia and dilated tubules were observed. Renal tubular cell necrosis, tubular degeneration/dilatation and eosinophilic casts were observed in the $50 \mathrm{mg} / \mathrm{kg}$ CMS-treated group. In the $25 \mathrm{mg} / \mathrm{kg}$ CMS-treated group, calcium levels were significantly increased, although no histopathological renal toxicity was observed. In the $50 \mathrm{mg} / \mathrm{kg}$ CMS-treated group, the BUN, CREA and calcium levels were increased, and renal lesions were observed in the histopathological analyses.

Overall, severe renal injury occurred in the $50 \mathrm{mg} / \mathrm{kg}$ CMS-treated rats, and renal injury was initiated by subacute treatment of $25 \mathrm{mg} / \mathrm{kg} \mathrm{CMS}$. Colistin has been shown to increase serum CREA levels in previous clinical and animal studies $(8,16)$. The biochemical and histopathological observations following CMS treatment in the present study are consistent with those of previous studies $(6,11)$. These results suggest that nephrotoxicity was induced by CMS treatment (25 and $50 \mathrm{mg} / \mathrm{kg}$ ) in the rat kidneys.

Global gene expression profiles in the kidney following CMS treatment. Microarray analysis of the three groups $(0$, 25 , and $50 \mathrm{mg} / \mathrm{kg} \mathrm{CMS}$ ) revealed 358 genes and 4,126 gene probe sets as DEGs by fold-change $(\geq 1.3, \mathrm{P}<0.05)$ from each group ( 25 and $50 \mathrm{mg} / \mathrm{kg}$ ) compared with the vehicle control. To remove false-positive genes, 27 and 886 significantly regulated genes were selected in the 25 and $50 \mathrm{mg} / \mathrm{kg}$ CMS-treated groups, respectively, following correction for multiple comparisons (FDR, $\mathrm{P}<0.05)$ and Tukey's HSD post hoc test. A total of 14 genes were selected as common 
Table II. Histology of CMS-treated rat kidneys.

Degree of presence (n)

\begin{tabular}{|c|c|c|c|}
\hline Histopathological finding & 0 & $25 \mathrm{mg} / \mathrm{kg} \mathrm{CMS}$ & $50 \mathrm{mg} / \mathrm{kg} \mathrm{CMS}$ \\
\hline Tubular degeneration/dilatation & - & - & $++(2),+++(4),++++(2)$ \\
\hline Tubular cell necrosis & - & - & $+(1),++(5),+++(2)$ \\
\hline Mineralization, tubules & - & - & $++(1),+++(1)$ \\
\hline Eosinophilic casts & - & - & $+(5),++(1)$ \\
\hline Infiltration, mononuclear & $+(1)$ & $+(1)$ & $+(4)$ \\
\hline Infiltration, mixed, pelvis & - & - & $+(1),++(1)$ \\
\hline Tubular basophilia & $+(1)$ & $+(3)$ & - \\
\hline Dilated tubules & - & $+(1)$ & - \\
\hline
\end{tabular}

Tissues with diagnoses $(25 \mathrm{mg} / \mathrm{kg}, \mathrm{n}=8 ; 50 \mathrm{mg} / \mathrm{kg}, \mathrm{n}=8) .+$, minimum or slight degree. ++ , slight degree or small amount;,+++ moderate, median, or middle severity or amount; ++++, marked severity or degree of change, large amount; +++++, highest degree or severity, maximum amount. CMS, colistin methanesulfonate.

Table III. Commonly expressed gene list and expression values of CMS-treated (25 and $50 \mathrm{mg} / \mathrm{kg}$ ) kidneys.

\begin{tabular}{|c|c|c|c|c|c|}
\hline \multirow[b]{2}{*}{$\begin{array}{l}\text { Gene } \\
\text { symbol }\end{array}$} & \multirow[b]{2}{*}{ Gene name } & \multicolumn{2}{|c|}{ Fold-change } & \multirow[b]{2}{*}{$\begin{array}{l}\text { Unadjusted } \\
\text { P-value }\end{array}$} & \multirow[b]{2}{*}{$\begin{array}{l}\text { Adjusted } \\
\text { FDR }\end{array}$} \\
\hline & & $\begin{array}{l}25 \mathrm{mg} / \mathrm{kg} \\
\mathrm{CMS}\end{array}$ & $\begin{array}{l}50 \mathrm{mg} / \mathrm{kg} \\
\mathrm{CMS}\end{array}$ & & \\
\hline Fitml & Fat storage-inducing transmembrane protein 1 & 1.95 & -1.88 & $1.62 \mathrm{E}-03$ & $<0.05$ \\
\hline Cirbp & Cold-inducible RNA binding protein & 1.66 & 2.19 & $1.50 \mathrm{E}-04$ & $<0.05$ \\
\hline Kifl $18 b$ & Kinesin family member $18 \mathrm{~B}$ & 1.38 & 2.03 & $5.78 \mathrm{E}-05$ & $<0.05$ \\
\hline $\operatorname{Inh} b b$ & Inhibin $\beta-\mathrm{B}$ & 1.37 & 2.36 & $7.28 \mathrm{E}-05$ & $<0.05$ \\
\hline Blm & Bloom syndrome, RecQ helicase-like & 1.33 & 1.48 & 7.93 E-04 & $<0.05$ \\
\hline Eif5 & Eukaryotic translation initiation factor 5 & -1.31 & -1.62 & $5.93 \mathrm{E}-06$ & $<0.05$ \\
\hline Trim59 & Tripartite motif-containing 59 & -1.32 & 1.44 & $9.21 \mathrm{E}-04$ & $<0.05$ \\
\hline Jun & Jun proto-oncogene & -1.32 & 1.57 & $2.00 \mathrm{E}-04$ & $<0.05$ \\
\hline Etnkl & Ethanolamine kinase 1 & -1.35 & -1.63 & $2.48 \mathrm{E}-04$ & $<0.05$ \\
\hline Cacybp & Calcyclin binding protein & -1.38 & -2.22 & $6.82 \mathrm{E}-04$ & $<0.05$ \\
\hline Avprla & Arginine vasopressin receptor $1 \mathrm{~A}$ & -1.64 & -2.62 & $1.54 \mathrm{E}-03$ & $<0.05$ \\
\hline Hsp90aal & $\begin{array}{l}\text { Heat shock protein } 90, \alpha \text { (cytosolic), } \\
\text { class A member } 1\end{array}$ & -1.66 & -1.56 & $1.11 \mathrm{E}-03$ & $<0.05$ \\
\hline Bmpr2 & $\begin{array}{l}\text { Bone morphogenetic protein receptor, } \\
\text { type II (serine/threonine kinase) }\end{array}$ & -1.69 & -2.08 & $9.11 \mathrm{E}-04$ & $<0.05$ \\
\hline Hsphl & Heat shock $105 / 110$ protein 1 & -1.81 & -2.52 & $1.63 \mathrm{E}-03$ & $<0.05$ \\
\hline
\end{tabular}

Fold-change was calculated as the relative average value of the CMS-treated group compared with the controls, with the values expressed as natural logarithms. Commonly expressed gene lists were selected in both conditions by unadjusted $\mathrm{P}<0.05$ ) and adjusted FDR $\mathrm{P}<0.05$ ). CMS, colistin methanesulfonate; FDR, false discovery rate.

genes in the two CMS treatment groups (Table III). Among the common genes, the expression levels of cold-inducible RNA binding protein (Cirbp), kinesin family member $18 \mathrm{~B}$ $(K i f 18 b)$, inhibin $\beta$-B (Inhbb) and bloom syndrome, RecQ helicase-like $(B l m)$ were increased, whereas those of eukaryotic translation initiation factor 5 (Eif5), ethanolamine kinase 1 (Etnk1), calcyclin binding protein (Cacybp), arginine vasopressin receptor 1A (Avprla), Hsp90aal, bone morpho- genetic protein receptor, type II (Bmpr2) and Hsph1 were decreased in the two CMS-treated groups. A total of 8 probe IDs for B-cell lymphoma ( $\mathrm{Bcl}-2)$-associated transcription factor 1 (Bclaf1), Dnajb (Hsp40) and zinc finger protein 423 (Zfp423) were differentially expressed in the $25 \mathrm{mg} / \mathrm{kg}$ CMS-treated group only. Dnajbl (Hsp40), Hsp90aal and $H s p h l$ are members of the Hsp family that protect the cell from proteotoxic and oxidative stress $(30,31)$, and these were 
Table IV. Representative gene lists and expression values of $50 \mathrm{mg} / \mathrm{kg}$ CMS-treated rats.

\begin{tabular}{|c|c|c|c|c|}
\hline Gene symbol & Gene name & Fold-change & $\begin{array}{l}\text { Unadjusted } \\
\text { P-value }\end{array}$ & $\begin{array}{l}\text { Adjusted } \\
\text { FDR }\end{array}$ \\
\hline \multicolumn{5}{|l|}{ Upregulated } \\
\hline Havcr1 & Hepatitis A virus cellular receptor 1 & 63.91 & $2.47 \mathrm{E}-05$ & $<0.05$ \\
\hline $\operatorname{Lcn} 2$ & Lipocalin 2 & 22.88 & $2.90 \mathrm{E}-04$ & $<0.05$ \\
\hline Gpnmb & Glycoprotein (transmembrane) $\mathrm{nmb}$ & 11.92 & $1.84 \mathrm{E}-05$ & $<0.05$ \\
\hline Spp1 & Secreted phosphoprotein 1 & 11.21 & $1.80 \mathrm{E}-03$ & $<0.05$ \\
\hline$C 4 a$ & Complement component $4 \mathrm{~A}$ & 11.04 & $2.02 \mathrm{E}-05$ & $<0.05$ \\
\hline$A k r l b 8$ & Aldo-keto reductase family 1, member B8 & 10.91 & $5.29 \mathrm{E}-05$ & $<0.05$ \\
\hline Serpinalo & $\begin{array}{l}\text { Serpin peptidase inhibitor, clade } \mathrm{A} \\
(\alpha-1 \text { antiproteinase, antitrypsin), member } 10\end{array}$ & 10.47 & 3.76 E-04 & $<0.05$ \\
\hline Clu & Clusterin & 9.91 & $6.51 \mathrm{E}-04$ & $<0.05$ \\
\hline Gpx2 & Glutathione peroxidase 2 & 9.69 & $2.20 \mathrm{E}-05$ & $<0.05$ \\
\hline Adamts 1 & $\begin{array}{l}\text { ADAM metallopeptidase with } \\
\text { thrombospondin type } 1 \text { motif, } 1\end{array}$ & 8.60 & $7.63 \mathrm{E}-05$ & $<0.05$ \\
\hline \multicolumn{5}{|l|}{ Downregulated } \\
\hline Klk1c4 & Kallikrein 1-related peptidase $\mathrm{C} 4$ & -43.64 & $5.11 \mathrm{E}-05$ & $<0.05$ \\
\hline Gtpbp4 & GTP binding protein 4 & -15.76 & $1.58 \mathrm{E}-05$ & $<0.05$ \\
\hline Klk1c9 & Kallikrein 1-related peptidase C9 & -7.73 & 1.45 E-04 & $<0.05$ \\
\hline Klklc7 & Kallikrein 1-related peptidase C7 & -7.40 & $1.50 \mathrm{E}-03$ & $<0.05$ \\
\hline $\operatorname{Tm} 4 s f 20$ & Transmembrane $4 \mathrm{~L}$ six family member 20 & -5.10 & $1.23 \mathrm{E}-03$ & $<0.05$ \\
\hline Sbspon & $\begin{array}{l}\text { Somatomedin B and thrombospondin, } \\
\text { type } 1 \text { domain-containing }\end{array}$ & -4.13 & $1.12 \mathrm{E}-03$ & $<0.05$ \\
\hline Mpped1 & Metallophosphoesterase domain-containing 1 & -3.43 & $1.57 \mathrm{E}-03$ & $<0.05$ \\
\hline Hacll & 2-Hydroxyacyl-CoA lyase 1 & -3.39 & $1.34 \mathrm{E}-03$ & $<0.05$ \\
\hline Gsta3 & Glutathione S-transferase A3 & -3.36 & $1.07 \mathrm{E}-03$ & $<0.05$ \\
\hline Mrap & Melanocortin 2 receptor accessory protein & -3.33 & $2.85 \mathrm{E}-02$ & $<0.05$ \\
\hline
\end{tabular}

Top 10 upregulated and downregulated gene lists were selected. Genes in bold are known nephrotoxic biomarker genes. The fold-change was calculated as the relative average value of the CMS-treated group compared with the controls, with the values expressed as natural logarithms. Representative expressed gene lists were selected in the two conditions by unadjusted $\mathrm{P}<0.05$ and adjusted FDR $\mathrm{P}<0.05$. CMS, CMS, colistin methanesulfonate.

downregulated by CMS. Dnajbl (Hsp40) interacts with Hsp70 and is induced by proteotoxic stress (32), Hsp90aal is expressed following proteotoxic stress and other conditions of cellular stress (32), and Hsphl encodes heat shock $105 / 110$ protein 1 and is induced by oxidative and proteotoxic stress (33).

The significant DEGs with the most marked changes in the $50 \mathrm{mg} / \mathrm{kg}$ CMS-treated group were selected (Table IV). Hepatitis A virus cellular receptor 1 (Havcrl), lipocalin 2 (Lcn2) and secreted phosphoprotein 1 (Sppl) are known to be representative nephrotoxicity biomarkers, and these genes showed high expression following CMS treatment. Kallikrein 1-related peptidase $\mathrm{C} 4(K l k l c 4), K l k l c 9$ and $K l k l c 7$ were significantly downregulated; these genes are associated with the kinin-kallikrein system, which is important for renal function (34). Gpx2 and Gsta3 were significantly upregulated and downregulated, respectively; these antioxidant genes are regulated by oxidative stress (35). These results indicated that gene sets associated with nephrotoxicity were also regulated by CMS under these experimental conditions.
Pathway analysis. In the $25 \mathrm{mg} / \mathrm{kg}$ CMS group, IPA revealed the significant canonical pathways were transforming growth factor (TGF)- $\beta$, bone morphogenetic protein (BMP) and androgen signaling. The canonical pathways of the $50 \mathrm{mg} / \mathrm{kg}$ CMS group were shown to be significant in eIF2, regulation of eIF4/p70S6K, mammalian target of rapamycin (mTOR), and aryl hydrocarbon receptor signaling, in addition to cell cycle control of chromosomal replication (Table V). The fold-changes of the top-ranked genes belonging to TGF- $\beta$ and eIF2 are also represented in Table VI. The canonical pathways associated with the upregulated and downregulated genes following $50 \mathrm{mg} / \mathrm{kg}$ CMS treatment were analyzed separately (Fig. 2A and B). Specifically, canonical pathways associated with protein translation, cell cycle control and apoptosis were predicted to be activated in the upregulated genes. In the canonical analysis of the downregulated genes, there was significance in pathways associated with amino acid metabolism and oxidative stress. The expression levels of genes involved in apoptosis and the cell cycle were upregulated, whereas the expression levels of genes involved in the 
Table V. Top regulated canonical pathway of DEGs from the CMS-treated kidney.

\begin{tabular}{lcc}
\hline Top canonical pathway & P-value & Overlapping ratio \% (n) \\
\hline CMS $(25 \mathrm{mg} / \mathrm{kg})$ & & $4.6(4 / 87)$ \\
TGF- $\beta$ signaling & $8.84 \mathrm{E}-07$ & $3.9(3 / 76)$ \\
BMP signaling pathway & $3.84 \mathrm{E}-05$ & $2.7(3 / 111)$ \\
Androgen signaling & $1.19 \mathrm{E}-04$ & $2.0(3 / 152)$ \\
Aldosterone signaling in epithelial cells & $3.00 \mathrm{E}-04$ & $1.7(3 / 179)$ \\
PPAR $\alpha /$ RXR activation & $4.85 \mathrm{E}-04$ & $25.4(47 / 185)$ \\
CMS $(50 \mathrm{mg} / \mathrm{kg})$ & & $17.1(25 / 146)$ \\
eIF2 signaling & $1.65 \mathrm{E}-28$ & $14.9(28 / 188)$ \\
Regulation of eIF4 and p70S6K signaling & $1.31 \mathrm{E}-11$ & $11.4(16 / 140)$ \\
mTOR signaling & $2.51 \mathrm{E}-11$ & $25.9(7 / 27)$ \\
Aryl hydrocarbon receptor signaling & $1.60 \mathrm{E}-05$ & $2.07 \mathrm{E}-05$ \\
Cell cycle control of chromosomal replication & & \\
\hline
\end{tabular}

CMS, colistin methanesulfonate; TGF- $\beta$, transforming growth factor- $\beta$; BMP, bone morphogenetic protein; PPAR, peroxisome proliferator-activated receptor; RXR, retinoid X receptor; eIF, eukaryotic initiation factor; mTOR, mammalian target of rapamycin.

Table VI. Expressional changes of genes involved in TGF- $\beta$, eIF2 and p53 signaling in CMS-treated kidneys.

\begin{tabular}{|c|c|c|}
\hline Gene symbol & Gene name & Fold-change $(\log 2)$ \\
\hline TGF- $\beta$ signaling & & $25 \mathrm{mg} / \mathrm{kg} \mathrm{CMS}$ \\
\hline $\operatorname{Inhbb}$ & Inhibin subunit $\beta B$ & 1.37 \\
\hline Znf423 & Zinc finger protein 423 & 1.31 \\
\hline Jun & Jun proto-oncogene, AP-1 transcription factor subunit & -1.33 \\
\hline Bmpr2 & Bone morphogenetic protein receptor type 2 & -1.70 \\
\hline eIF2 signaling & & $50 \mathrm{mg} / \mathrm{kg} \mathrm{CMS}$ \\
\hline Nras & NRAS proto-oncogene, gtpase & 1.84 \\
\hline Rps19 & Ribosomal protein S19 & 1.82 \\
\hline Rpl36a & Ribosomal protein L36A & 1.78 \\
\hline Rps 28 & Ribosomal protein $\mathrm{S} 28$ & 1.72 \\
\hline Rpsa & Ribosomal protein SA & 1.72 \\
\hline Rpl18a & Ribosomal protein 118a & 1.70 \\
\hline $\operatorname{Pik} 3 c 2 b$ & Phosphatidylinositol-4-phosphate 3-kinase catalytic subunit type $2 \beta$ & 1.69 \\
\hline Rpl3 & Ribosomal protein L3 & 1.69 \\
\hline Rpl13 & Ribosomal protein L13 & 1.63 \\
\hline Eif5 & Eukaryotic translation initiation factor 5 & -2.08 \\
\hline p53 signaling & & $50 \mathrm{mg} / \mathrm{kg} \mathrm{CMS}$ \\
\hline Apafl & Apoptotic peptidase activating factor 1 & 1.18 \\
\hline Cdknla & Cyclin dependent kinase inhibitor 1A & 0.92 \\
\hline Fas & Fas cell surface death receptor & 0.92 \\
\hline$C d k 4$ & Cyclin dependent kinase 4 & 0.80 \\
\hline $\operatorname{Pik} 3 c 2 b$ & Phosphatidylinositol-4-phosphate 3-kinase catalytic subunit type $2 \beta$ & 0.76 \\
\hline$B b c 3$ & BCL2 binding component 3 & 0.74 \\
\hline Jun & Jun proto-oncogene, AP-1 transcription factor subunit & 0.66 \\
\hline Csnkld & Casein kinase $1 \delta$ & 0.52 \\
\hline Hipk2 & Homeodomain interacting protein kinase 2 & -0.48 \\
\hline Kat $2 b$ & Lysine acetyltransferase 2B & -0.78 \\
\hline
\end{tabular}

Fold-change was calculated as the relative average value of the CMS-treated group compared with controls, and the values are expressed as natural logarithms. For eIF2 signaling, 45 genes were upregulated and one gene was downregulated in the $50 \mathrm{mg} / \mathrm{kg} \mathrm{CMS}$-treated group; the fold-changes of the 10 top-ranked genes are provided. CMS, colistin methanesulfonate; TGF- $\beta$, transforming growth factor- $\beta$; eIF2, eukaryotic translation initiation factor 2 . 
A

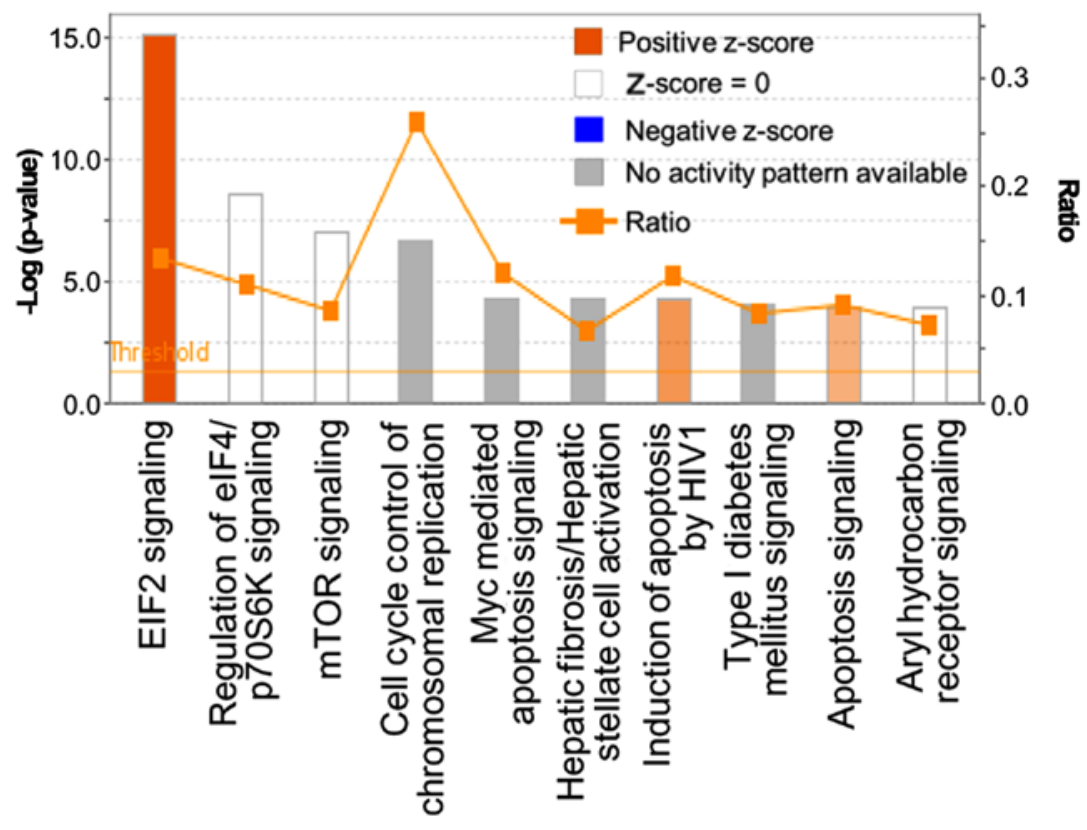

B

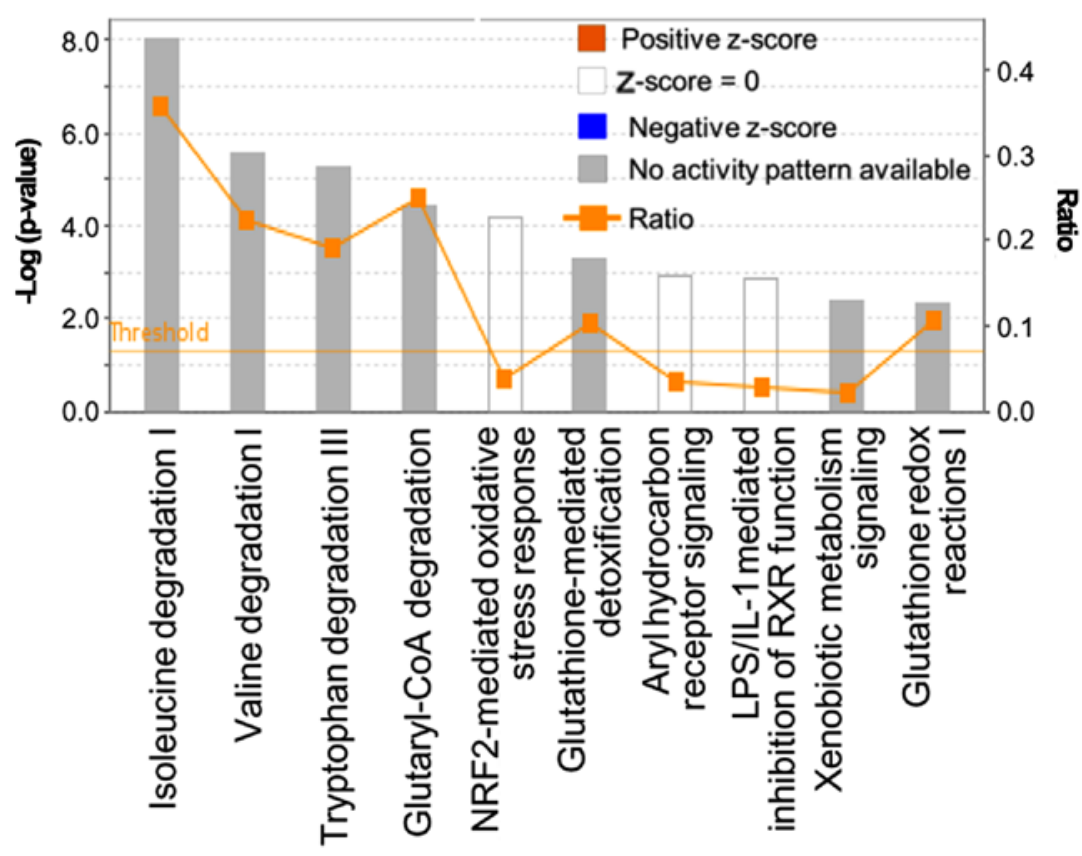

Figure 2. Canonical pathway analysis of DEGs in $50 \mathrm{mg} / \mathrm{kg}$ CMS-treated rat kidneys. Metabolic and signaling pathway analysis in (A) upregulated and (B) downregulated DEGs. The default y-axis displays the -log of the P-value, which was calculated using Fisher's exact test (right-tailed). The orange points connected by a thin line represent the ratio. The ratio was calculated as the number of genes in a given pathway that meet the cut-off criteria/total number of genes in the pathway and reference gene set. The orange and blue bars indicate predicted pathway activation or inhibition, respectively (z-score). White bars indicate a z-score at or close to 0 . The gray bars indicate pathways where no prediction can be made. CMS, colistin methanesulfonate; DEGs, differentially expressed genes.

protective response to oxidative stress were downregulated in the $50 \mathrm{mg} / \mathrm{kg}$ CMS-treated group.

Several investigations have reported that TGF- $\beta$ and BMP signaling are significantly affected by nephrotoxic compounds, including tacrolimus and cyclosporine (36,37). TGF- $\beta$ acts as a key mediator in renal disease given its functions in renal inflammation, apoptosis and differentiation (38). BMPs belong to the TGF- $\beta$ family, and TGF- $\beta$ /BMP signaling is important in kidney development and renal cell proliferation (39). This result demonstrated that TGF- $\beta$ /BMP signalling may be activated to cause proliferation of kidney cells following the initial damage caused by CMS. eIF2, regulation of eIF4 and p70S6K, and the mTOR signalling pathway were significantly altered following CMS treatment. These pathways are activated for survival and recovery from cellular stresses, including oxidative or proteotoxic stress $(40,41)$. 
A

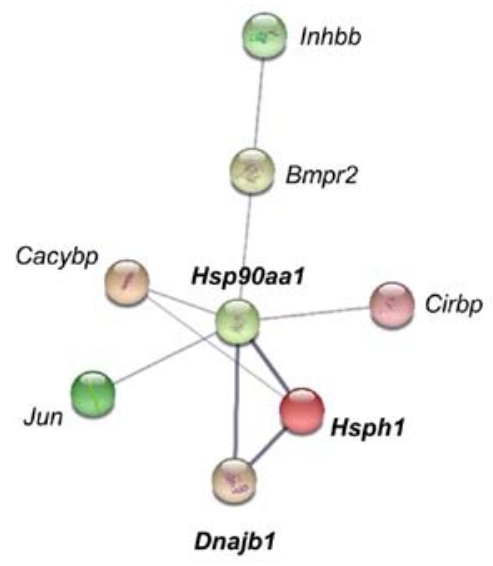

B

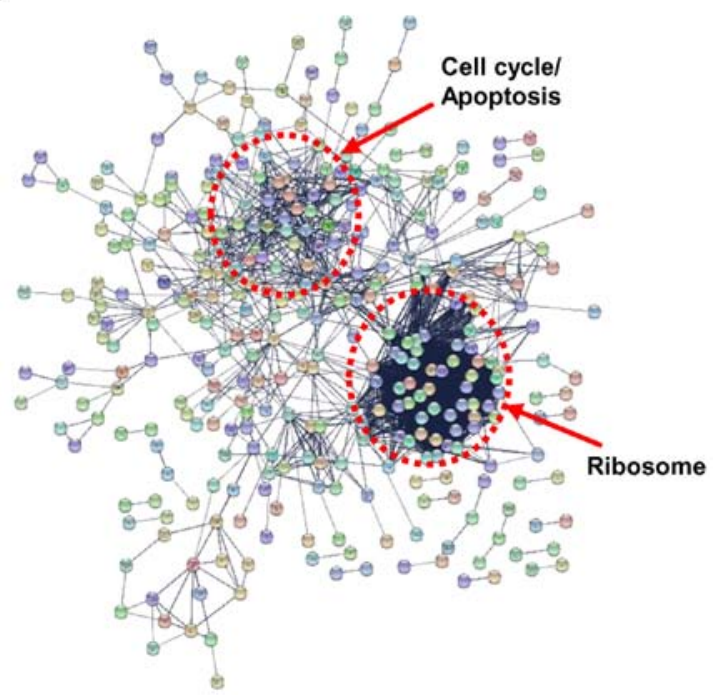

Figure 3. PPI analysis of the DEGs of CMS-treated rat kidneys. Confidence view. The PPI networking is shown as nodes (proteins) and edges/lines (interactions). The confidence of an interaction is reflected by the thickness of the edge. Closer associations are represented by thicker lines. (A) 27 DEGs from the $25 \mathrm{mg} / \mathrm{kg}$ CMS treatment group had a confidence score $>0.400$. (B) 886 DEGs from the CMS (50 mg/kg) treatment group had a confidence score $>0.700$. The predicted interactions are indicated as lines between the transcription factors and target genes. PPI, protein-protein interaction; CMS, colistin methanesulfonate; DEGs, differentially expressed genes.

A

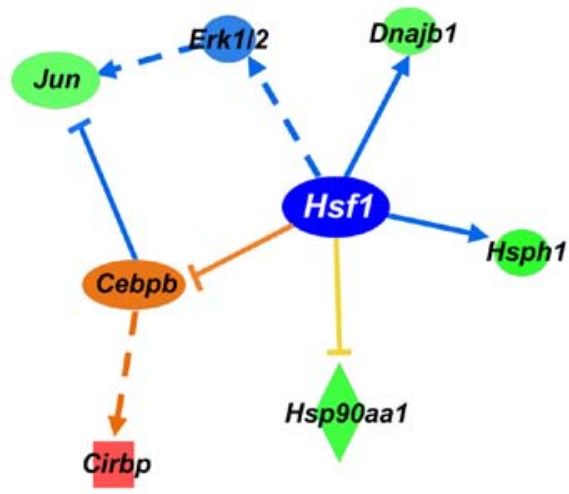

B

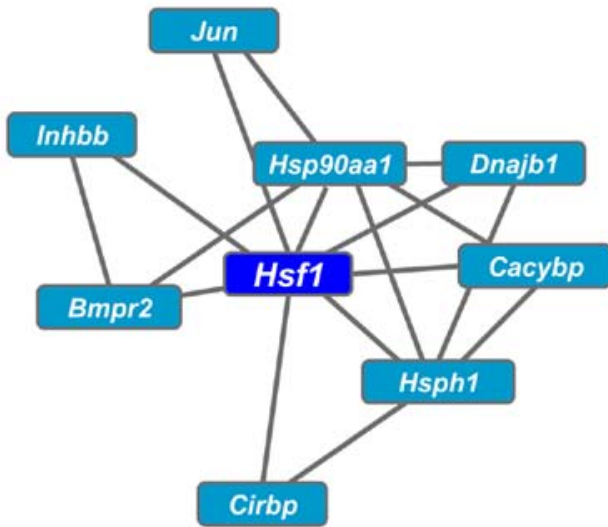

Figure 4. Analysis of master regulator genes of DEGs in the $25 \mathrm{mg} / \mathrm{kg} \mathrm{CMS}$-treated group. Hsfl was selected as a master regulator for both analyses. (A) Upstream regulator analysis using Ingenuity Pathway Analysis. Red indicates upregulated expression and green indicates downregulated expression. Predictions of the effects of the transcription factor are shown in orange and blue, with orange indicating the prediction of activation and blue indicating the prediction of inhibition. Yellow indicates inconsistencies in the downstream molecules. (B) Analysis of the transcription factor regulating the DEGs using iRegulon. CMS, colistin methanesulfonate; DEGs, differentially expressed genes.

PPI and upstream regulator analysis. PPI analysis was performed with the DEGs from each group using STRING (v.10) software (Fig. 3). With the DEGs identified in the $25 \mathrm{mg} / \mathrm{kg}$ CMS treatment group, the protein interaction analysis showed connections among Hsphl, Hsp90aal, Dnajbl, Jun proto-oncogene (Jun), Cacybp, Bmpr2 and Inhbb with a confidence score of 0.400 (Fig. 3A). In particular, strong associations were observed among Hsphl, Hsp90 and Dnajbl (Hsp40), and the heat shock factor 1 (Hsfl) transcription factor is known to regulate the expression of these genes. The protein interaction analysis of the DEGs of the $50 \mathrm{mg} / \mathrm{kg}$ CMS treatment group, conducted with a confidence score of 0.700 , is shown in Fig. 3B. The PPI pathways were primarily grouped into ribosome, cell cycle, and apoptosis categories using KEGG pathway enrichment. The PPI analysis indicated that Hsphl, Hsp90 and Dnajbl function as key nodes in the gene regulatory network during initial nephrotoxicity induced by $25 \mathrm{mg} / \mathrm{kg}$ CMS treatment.

To define the key regulators that trigger colistin-induced nephrotoxicity, transcriptional regulators of the DEGs following CMS treatment $(25 \mathrm{mg} / \mathrm{kg})$ were analyzed using IPA and Cytoscape software iRegulon. Hsfl was selected as the primary gene based on the upstream and causal analysis of IPA. The IPA analysis revealed that $H s f l$ regulates the expression of Hspl, Hsp90aal, Dnajbl (Hsp40), Jun and Cirbp (Fig. 4A). Hsfl is predicted to inhibit the expression of its target gene. Hsfl was also selected as the top transcription factor in the iRegulon analysis (Fig. 4B). Collectively, Hsfl was identified as a master transcription factor regulating gene expression in colistin-induced nephrotoxicity. 
To validate the microarray data, RT-qPCR analysis was conducted (Fig. 5). Analysis of the expression of Hsfl target genes and Nrf2-mediated oxidative stress genes by microarray and RT-qPCR analyses indicated that these methods produced similar results. The expression levels of Dnajbl, Hsphl and Hsp90aal were inhibited by both doses of CMS (Fig. 5A). With $25 \mathrm{mg} / \mathrm{kg}$ CMS treatment, no significant changes were observed in the expression levels of Nrf2-mediated oxidative stress genes when analyzed by microarray and RT-qPCR analyses (data not shown). However, the expression of Nrf2-mediated oxidative stress genes were significantly altered in the $50 \mathrm{mg} / \mathrm{kg}$ CMS-treated group; these results were consistent in both analyses (Fig. 5B). The expression of $H s f l$ target genes and Nrf2-mediated oxidative stress genes were confirmed by RT-qPCR analysis.

Hsf1 is a major transcriptional regulator that binds heat shock elements in the promoter of heat shock proteins (42) and triggers the activation of $H s p$ genes in response to environmental stresses (43). Hsf1 is critical in regulating physiological events during development and pathological conditions (43). It has been reported that nephrotoxic compounds induce the synthesis of Hsp proteins in the kidney prior to the increase in classical biochemical markers for nephrotoxicity becoming apparent (44). Cyclosporine, a nephrotoxic drug, induces a heat shock response (45) and Di (2-ethylhexyl) phthalate also induces nephrotoxicity by inhibiting the HSF-dependent heat shock response (46). In the present study, the activity of Hsf1 was predicted, and its target genes increased with CMS treatment. This finding demonstrated that Hsf1 may be a key regulator in defense against pathological lesions in the kidney through activation of the heat shock response.

Mapping the canonical pathway of DEGs to an AOP. A number of AOP frameworks associated with nephrotoxicity have been investigated as part of the OECD work plan (https://www.aopkb.oecd.org). Cyclooxygenase 1 and agonism of the estrogen receptor have been suggested as potential MIEs, although there is limited understanding of MIE and KE molecules. The present study suggested a putative framework for a nephrotoxicity AOP that integrates -omics data, blood biochemistry, histopathology and data from publications on colistin-induced nephrotoxicity, although further validation is necessary to build an AOP model with a sufficient weight of evidence. In the present study, serum and histological observations suggested that nephrotoxicity resulted from CMS, and key pathways and master regulatory were comprehensively analyzed based on phenotype-anchored gene expression profiles. The phenotype-anchored gene expression and observed high expression of well-known nephrotoxic biomarkers, including the Kiml (hepatitis A virus cellular receptor 1), Lcn2, Sppl and Klklc families, were analyzed in the group treated with $50 \mathrm{mg} / \mathrm{kg}$ CMS. The key pathways and master regulators associated with the nephrotoxicity induced by CMS were then analyzed. The gene expression of heat shock-related proteins was significantly inhibited in the low-dose group, and the inhibition of the heat shock response may be a potential MIE. In the master regulator gene analysis, it was found that $H s f l$ significantly regulated the expression of those genes in the CMS-treated kidney $(25 \mathrm{mg} / \mathrm{kg})$. Proteotoxic stress is triggered by an imbalance of proteostasis, which is a biological pathway that maintains cellular homeostasis from cellular stress and is predominantly controlled by Hsf1 (47-49). To maintain proteostasis, the proteostasis network is regulated by ribosomes, chaperones and the proteasome (50). Chaperones, including HSPs, function to prevent protein misfolding and maintain protein homeostasis, and the transcription of these genes is regulated by HSFs $(51,52)$.

Previous studies have shown that colistin binds to the $\mathrm{N}$-domain of HSP 90 and suppresses chaperone activity $(53,54)$. Therefore, it is hypothesized that colistin binds to Hsp90 and inhibits the transcriptional activity of Hsf1. As a result, proteotoxicity is induced due to decreased protective function against stress. From these results, a potential MIE was predicted through a process in which hsp90 is bound to a drug and induces proteotoxicity.

The KEs and KERs were predicted by the canonical pathways of the DEGs and data from other publications. Based on the results of the pathway analysis, it was possible to identify KEs at the molecular level and develop the structure of the framework by linking the KERs with literature data. In the pathway analysis of the upregulated DEGs following $50 \mathrm{mg} / \mathrm{kg}$ CMS treatment, it was found that the important pathways were eIF2, regulation of eIF4/p70S6K, mTOR, apoptosis signaling, and cell cycle control. In the pathway analysis of the downregulated DEGs, the important pathways were amino acid degradation, Nrf2-mediated oxidative stress response and glutathione-mediated detoxification signaling. In addition, ribosomes, cell cycle arrest, and apoptosis pathways were selected as representative pathways in the PPI analysis.

Proteotoxic stress can be induced by the impairment of cellular function caused by protein misfolding (50). The signaling pathways associated with translation factors, including eIF2 and eIF4, are modulated for recovery from proteotoxic stress $(41,55)$. mTOR signaling is related to responses to proteotoxic stress and is also related to HSF activation and synthesis of HSPs (40). The expression of antioxidant genes ( $\operatorname{Sod}$ and Gpx) are downregulated by CMS, as observed in previous investigations (14). Nrf2-mediated oxidative stress signaling and glutathione signaling are known to be involved in oxidative stress, and the expression levels of these genes are downregulated by CMS treatment (56). This indicates that the antioxidant response is inhibited by colistin. Cell cycle arrest and apoptosis signaling via the mitochondrial, death receptor, and endoplasmic reticulum pathways have already been shown to be involved in colistin-induced nephrotoxicity $(14,15)$. In the present study, genes related to p53 signaling were also significantly differentially regulated in the CMS-treated kidneys (Table VI). This suggested that these pathways are KEs of this AOP and that these KEs are related to each other.

The present study hypothesized that proteotoxic stress may occur through the suppression of HSPs and the antioxidant response. It was hypothesized that oxidative stress and ER stress are involved as KEs through the activation of eIF2 signaling and mTOR signaling. In addition, cell cycle arrest and apoptosis represents major events in cell death, and these major pathways may be elements of KEs. The binding of colistin to HSP90 inhibits chaperone activity and induces proteotoxic stress, which results in oxidative stress. ROS 
A

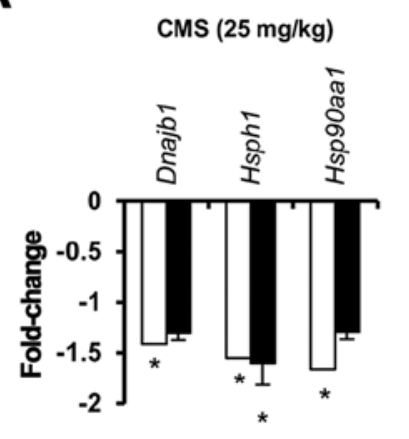

B

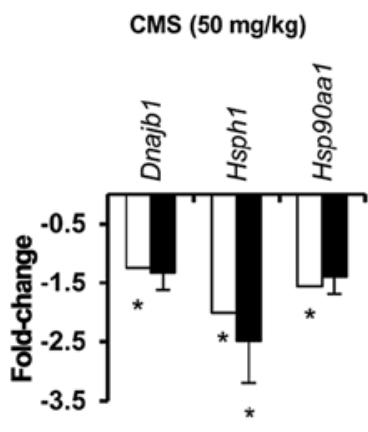

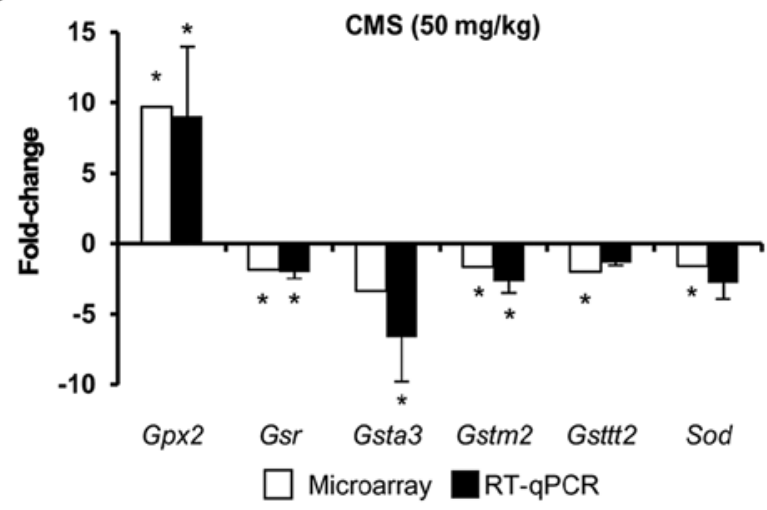

Figure 5. Verification of Hsfl target genes and Nrf2-mediated oxidative stress genes. (A) Validation of the expression of $H s f 1$ target genes from CMS-treated $(25$ and $50 \mathrm{mg} / \mathrm{kg}$ ) rat kidneys. (B) Validation of the expression of genes related to Nrf2-mediated oxidative stress from $50 \mathrm{mg} / \mathrm{kg}$ CMS-treated rat kidneys. The fold-changes of genes from the microarray data have statistical significance based on calculation of adjusted false discovery rate $\left({ }^{*} \mathrm{P}<0.05\right.$ compared with controls). The P-value from the RT-qPCR results was calculated using Student's t-test ( $\mathrm{P}<0.05$ compared with controls). The relative fold-change values are represented as natural logarithms. CMS, colistin methanesulfonate; RT-qPCR, reverse transcription-quantitative polymerase chain reaction.

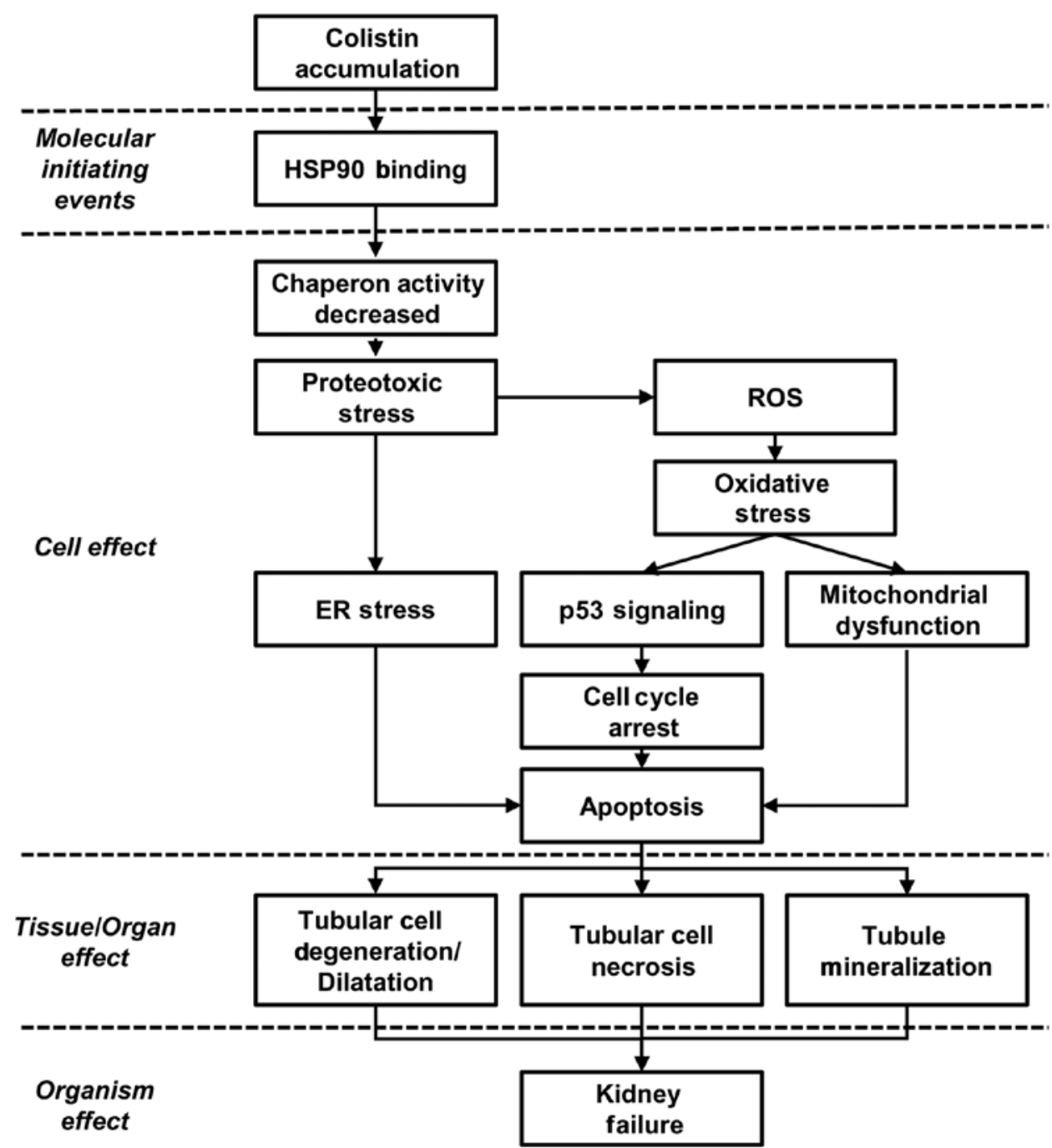

Figure 6. Putative adverse outcome pathway framework for colistin-induced nephrotoxicity. Each box indicates cell and tissue/organ effects representing a key event. ROS, reactive oxygen species; ER, endoplasmic reticulum.

produced by oxidative stress induces ER stress, mitochondrial injury, cell cycle arrest and apoptosis, leading to cell death. These KEs have been confirmed in the results of previous publications (14). The AOP of renal toxicity can be explained by the biochemical and histopathological results in addition to analysis of previous literature (Fig. 6). 
In the present study, a putative AOP for nephrotoxicity induced by colistin was suggested using global gene expression profiling. Omics approaches are considered suitable tools to provide information on putative AOPs. Gene expression changes can offer molecular insights regarding the initial events, but have limitations as they reflect a snapshot of a rapidly changing gene set in certain circumstances. Despite the limitations of microarray approaches, further information on MIE and KEs is required to develop the AOP networking model. However, AOPs ultimately aim to suggest qualitative or quantitative approaches to assess toxicity, and further validation is necessary to strengthen the weight of evidence for the putative AOP model.

In conclusion, gene expression analysis was performed in the present study to evaluate the mechanism of nephrotoxicity induced by colistin. It was found that the expression levels of HSF1 target genes, including Hsp90aal, Hsphl and Dnajbl ( $H s p 40)$, were downregulated by colistin, and the expression levels of Nrf2-mediated oxidative stress genes were also downregulated following treatment with a high dose of colistin. HSF1 and Nrf2 are known to be associated with protection against various forms of stress and to compensate for each other (57). Based on these results, a framework for an AOP of colistin-induced nephrotoxicity was constructed, which can facilitate an improved understanding of the mechanism of renal toxicity.

\section{Acknowledgements}

Not applicable.

\section{Funding}

The present study was supported by the Ministry of Food and Drug Safety (grant no. 13182MFDS988), the Ministry of Science and ICT (grant no. NRF-2016M3A9C4953144), the Ministry of Education (grant no. 2017R1A6A3A01011544) and the Korea Institute of Toxicology (grant no. KK-1801).

\section{Availability of data and materials}

All data generated or analysed during the present study are included in this published article.

\section{Authors' contributions}

EHL contributed to the analysis and interpretation of data and was involved in drafting the manuscript. SK and MSC contributed to analysis of microarray data. HY contributed to RT-qPCR analysis. SMP and HAO contributed to the microarray experiment. KSM contributed to the animal experiments. JSH and YBK contributed to histopathologic observation. SY and JHO contributed to conception and design of the study and revised the manuscript critically.

\section{Ethics approval and consent to participate}

All experiments were approved by the IACUC of Korea Institute of Toxicology (approval no. 1404-0120) and conducted in accordance with the Association of Assessment and Accreditation of Laboratory Animal Care International guidelines.

\section{Patient consent for publication}

Not applicable.

\section{Competing interests}

The authors declare that they have no competing interests.

\section{References}

1. Bergen PJ, Li J, Rayner CR and Nation RL: Colistin methanesulfonate is an inactive prodrug of colistin against Pseudomonas aeruginosa. Antimicrob Agents Chemother 50: 1953-1958, 2006.

2. Nation RL and Li J: Colistin in the 21st century. Curr Opin Infect Dis 22: 535-543, 2009.

3. Falagas ME and Kasiakou SK: Colistin: The revival of polymyxins for the management of multidrug-resistant gram-negative bacterial infections. Clin Infect Dis 40: 1333-1341, 2005.

4. Evans ME, Feola DJ and Rapp RP: Polymyxin B sulfate and colistin: Old antibiotics for emerging multiresistant gram-negative bacteria. Ann Pharmacother 33: 960-967, 1999.

5. Li J, Nation RL, Turnidge JD, Milne RW, Coulthard K, Rayner R and Paterson DL: Colistin: The re-emerging antibiotic for multidrug-resistant Gram-negative bacterial infections. Lancet Infect Dis 6: 589-601, 2006.

6. Wallace SJ, Li J, Nation RL, Rayner CR, Taylor D, Middleton D, Milne RW, Coulthard K and Turnidge JD: Subacute toxicity of colistin methanesulfonate in rats: Comparison of various intravenous dosage regimens. Antimicrob Agents Chemother 52: 1159-1161, 2008.

7. Ma Z, Wang J, Nation RL, Li J, Turnidge JD, Coulthard K and Milne RW: Renal disposition of colistin in the isolated perfused rat kidney. Antimicrob Agents Chemother 53: 2857-2864, 2009.

8. Spapen H, Jacobs R, Van Gorp V, Troubleyn J and Honoré PM: Renal and neurological side effects of colistin in critically ill patients. Ann Intensive Care 1: 14, 2011.

9. Dropulic LK and Cohen JI: Severe viral infections and primary immunodeficiencies. Clin Infect Dis 53: 897-909, 2011.

10. Price DJ and Graham DI: Effects of large doses of colistin sulphomethate sodium on renal function. BMJ 4: 525-527, 1970.

11. Hartzell JD, Neff R, Ake J, Howard R, Olson S, Paolino K, Vishnepolsky M, Weintrob A and Wortmann G: Nephrotoxicity associated with intravenous colistin (colistimethate sodium) treatment at a tertiary care medical center. Clin Infect Dis 48: 1724-1728, 2009.

12. Yousef JM, Chen G, Hill PA, Nation RL and Li J: Ascorbic acid protects against the nephrotoxicity and apoptosis caused by colistin and affects its pharmacokinetics. J Antimicrob Chemother 67: 452-459, 2012.

13. Ozkan G, Ulusoy S, Orem A, Alkanat M, Mungan S, Yulug E and Yucesan FB: How does colistin-induced nephropathy develop and can it be treated? Antimicrob Agents Chemother 57: 3463-3469, 2013.

14. Dai C, Li J, Tang S, Li J and Xiao X: Colistin-induced nephrotoxicity in mice involves the mitochondrial, death receptor, and endoplasmic reticulum pathways. Antimicrob Agents Chemother 58: 4075-4085, 2014.

15. Eadon MT, Hack BK, Alexander JJ, Xu C, Dolan ME and Cunningham PN: Cell cycle arrest in a model of colistin nephrotoxicity. Physiol Genomics 45: 877-888, 2013.

16. Yousef JM, Chen G, Hill PA, Nation RL and Li J: Melatonin attenuates colistin-induced nephrotoxicity in rats. Antimicrob Agents Chemother 55: 4044-4049, 2011.

17. Ghlissi Z, Hakim A, Sila A, Mnif H, Zeghal K, Rebai T, Bougatef $A$ and Sahnoun Z: Evaluation of efficacy of natural astaxanthin and vitamin $\mathrm{E}$ in prevention of colistin-induced nephrotoxicity in the rat model. Environ Toxicol Pharmacol 37: 960-966, 2014.

18. Dai C, Tang S, Deng S, Zhang S, Zhou Y, Velkov T, Li J and Xiao X: Lycopene attenuates colistin-induced nephrotoxicity in mice via activation of the $\mathrm{Nrf} 2 / \mathrm{HO}-1$ pathway. Antimicrob Agents Chemother 59: 579-585, 2015. 
19. Bourdon-Lacombe JA, Moffat ID, Deveau M, Husain M Auerbach S, Krewski D, Thomas RS, Bushel PR, Williams A and Yauk CL: Technical guide for applications of gene expression profiling in human health risk assessment of environmental chemicals. Regul Toxicol Pharmacol 72: 292-309, 2015

20. LaLone CA, Ankley GT, Belanger SE, Embry MR, Hodges G, Knapen D, Munn S, Perkins EJ, Rudd MA, Villeneuve DL, et al: Advancing the adverse outcome pathway framework-An international horizon scanning approach. Environ Toxicol Chem 36: 1411-1421, 2017.

21. Wittwehr C, Aladjov H, Ankley G, Byrne HJ, de Knecht J, Heinzle E, Klambauer G, Landesmann B, Luijten M, MacKay C, et al: How adverse outcome pathways can aid the development and use of computational prediction models for regulatory toxicology. Toxicol Sci 155: 326-336. 2017.

22. Brockmeier EK, Hodges G, Hutchinson TH, Butler E, Hecker M Tollefsen KE, Garcia-Reyero N, Kille P, Becker D, Chipman K, et al: The role of omics in the application of adverse outcome pathways for chemical risk assessment. Toxicol Sci 158: 252-262. 2017.

23. Lowthert L, Leffert J, Lin A, Umlauf S, Maloney K, Muralidharan A, Lorberg B, Mane S, Zhao H, Sinha R, et al: Increased ratio of anti-apoptotic to pro-apoptotic $\mathrm{Bcl} 2$ genefamily members in lithium-responders one month after treatment initiation. Biol Mood Anxiety Disord 2: 15, 2012.

24. Jiménez-Marín Á, Collado-Romero M, Ramirez-Boo M, Arce C and Garrido JJ: Biological pathway analysis by ArrayUnlock and ingenuity pathway analysis. BMC Proc 3 (Suppl 4): S6, 2009

25. Cline MS, Smoot M,CeramiE,Kuchinsky A,Landys N, Workman C, Christmas R, Avila-Campilo I, Creech M, Gross B, et al: Integration of biological networks and gene expression data using Cytoscape. Nat Protoc 2: 2366-2382, 2007.

26. Son MY, Kim YD, Seol B, Lee MO, Na HJ, Yoo B, Chang JS and Cho YS: Biomarker Discovery by Modeling Behçet's Disease with Patient-Specific Human Induced Pluripotent Stem Cells. Stem Cells Dev 26: 133-145, 2017.

27. Szklarczyk D, Franceschini A, Kuhn M, Simonovic M, Roth A, Minguez P, Doerks T, Stark M, Muller J, Bork P, et al: The STRING database in 2011: Functional interaction networks of proteins, globally integrated and scored. Nucleic Acids Res 39 (Database): D561-D568, 2011.

28. Kanehisa M, Goto S, Furumichi M, Tanabe M and Hirakawa M KEGG for representation and analysis of molecular networks involving diseases and drugs. Nucleic Acids Res 38: D355-D360, 2010.

29. Livak KJ and Schmittgen TD: Analysis of relative gene expression data using real-time quantitative PCR and the $2{ }^{-\Delta \Delta} \mathrm{CT}$ method. Methods 25: 402-408. 2001.

30. Santoro MG: Heat shock factors and the control of the stress response. Biochem Pharmacol 59: 55-63, 2000.

31. Morimoto RI: Proteotoxic stress and inducible chaperone networks in neurodegenerative disease and aging. Genes Dev 22: $1427-1438,2008$

32. Hensen SM, Heldens L, van Enckevort CM, van Genesen ST, Pruijn GJ and Lubsen NH: Heat shock factor 1 is inactivated by amino acid deprivation. Cell Stress Chaperones 17: 743-755, 2012.

33. Qiao S, Lamore SD, Cabello CM, Lesson JL, Muñoz-Rodriguez JL and Wondrak GT: Thiostrepton is an inducer of oxidative and proteotoxic stress that impairs viability of human melanoma cells but not primary melanocytes. Biochem Pharmacol 83: 1229-1240, 2012.

34. Moreau ME, Garbacki N, Molinaro G, Brown NJ, Marceau F and Adam A: The kallikrein-kinin system: Current and future pharmacological targets. J Pharmacol Sci 99: 6-38, 2005.

35. Li S, Tan HY, Wang N, Zhang ZJ, Lao L, Wong CW and Feng Y: The role of oxidative stress and antioxidants in liver diseases. Int J Mol Sci 16: 26087-26124, 2015.

36. Khanna A, Plummer M, Bromberek C, Bresnahan B and Hariharan S: Expression of TGF- $\beta$ and fibrogenic genes in transplant recipients with tacrolimus and cyclosporine nephrotoxicity. Kidney Int 62: 2257-2263, 2002.

37. Shehata M, Cope GH, Johnson TS, Raftery AT and el Nahas AM: Cyclosporine enhances the expression of TGF- $\beta$ in the juxtaglomerular cells of the rat kidney. Kidney Int 48: 1487-1496, 1995.
38. Böttinger EP and Bitzer M: TGF-beta signaling in renal disease. J Am Soc Nephrol 13: 2600-2610, 2002.

39. Meng X-M, Chung AC and Lan HY: Role of the TGF- $\beta$ / BMP-7/Smad pathways in renal diseases. Clin Sci (Lond) 124: 243-254, 2013

40. Chou SD, Prince T, Gong J and Calderwood SK: mTOR is essential for the proteotoxic stress response, HSF1 activation and heat shock protein synthesis. PLoS One 7: e39679, 2012.

41. Liu B and Qian SB: Translational reprogramming in cellular stress response. Wiley Interdiscip Rev RNA 5: 301-315, 2014

42. Xiao X, Zuo X, Davis AA, McMillan DR, Curry BB, Richardson JA and Benjamin IJ: HSF1 is required for extra-embryonic development, postnatal growth and protection during inflammatory responses in mice. EMBO J 18: 5943-5952, 1999.

43. Anckar J and Sistonen L: Regulation of HSF1 function in the heat stress response: Implications in aging and disease. Annu Rev Biochem 80: 1089-1115, 2011.

44. Dunđerski JS: Cellular stress response - Defence against metal toxicity. Jugoslovenska Medicinska Biohemija 23: 1-9, 2004.

45. Paslaru L, Rallu M, Manuel M, Davidson S and Morange M: Cyclosporin A induces an atypical heat shock response. Biochem Biophys Res Commun 269: 464-469, 2000.

46. Li P-C, Li X-N, Du Z-H, Wang H, Yu Z-R and Li JL: Di (2-ethyl hexyl) phthalate (DEHP)-induced kidney injury in quail (Coturnix japonica) via inhibiting HSF1/HSF3-dependent heat shock response. Chemosphere 209: 981-988, 2018.

47. Pirkkala L, Nykänen P and Sistonen L: Roles of the heat shock transcription factors in regulation of the heat shock response and beyond. FASEB J 15: 1118-1131, 2001

48. Dai S, Tang Z, Cao J, Zhou W, Li H, Sampson S and Dai C: Suppression of the HSF1-mediated proteotoxic stress response by the metabolic stress sensor AMPK. EMBO J 34: 275-293, 2015.

49. Niforou K, Cheimonidou C and Trougakos IP: Molecular chaperones and proteostasis regulation during redox imbalance. Redox Biol 2: 323-332, 2014.

50. Arnsburg K and Kirstein-Miles J: Interrelation between protein synthesis, proteostasis and life span. Curr Genomics 15: 66-75, 2014.

51. Akerfelt M, Morimoto RI and Sistonen L: Heat shock factors: Integrators of cell stress, development and lifespan. Nat Rev Mol Cell Biol 11: 545-555, 2010.

52. Verghese J, Abrams J, Wang Y and Morano KA: Biology of the heat shock response and protein chaperones: Budding yeast (Saccharomyces cerevisiae) as a model system. Microbiol Mol Biol Rev 76: 115-158, 2012.

53. Togashi S, Takahashi K, Tamura A, Toyota I, Hatakeyama S, Komatsuda A, Kudo I, Sasaki Kudoh E, Okamoto T, Haga A, et al: High dose of antibiotic colistin induces oligomerization of molecular chaperone HSP90. J Biochem 162: 27-36, 2017.

54. Minagawa S, Kondoh Y, Sueoka K, Osada $\mathrm{H}$ and Nakamoto $\mathrm{H}$ : Cyclic lipopeptide antibiotics bind to the $\mathrm{N}$-terminal domain of the prokaryotic Hsp90 to inhibit the chaperone activity. Biochem J 435: 237-246, 2011

55. Liu B, Han Y and Qian SB: Cotranslational response to proteotoxic stress by elongation pausing of ribosomes. Mol Cell 49: 453-463, 2013.

56. Schieber M and Chandel NS: ROS function in redox signaling and oxidative stress. Curr Biol 24: R453-R462, 2014.

57. Dayalan Naidu S, Kostov RV and Dinkova-Kostova AT: Transcription factors Hsf1 and Nrf2 engage in crosstalk for cytoprotection. Trends Pharmacol Sci 36: 6-14, 2015.

This work is licensed under a Creative Commons Attribution-NonCommercial-NoDerivatives 4.0 International (CC BY-NC-ND 4.0) License. 